\title{
Bedload transport as an indicator of contemporary transformations of arctic fluvial systems
}

\author{
W. Kociuba, G. Janicki, K. Siwek \& A. Gluza \\ Faculty of Earth Sciences and Spatial Management, \\ Maria Curie-Skłodowska University in Lublin, Poland
}

\begin{abstract}
The article presents results of measurements of bedload transport rate, performed during the ablation season 2010 in the gravel-bed Scott River catchment (Svalbard). The study revealed temporal and spatial variability of bedload transport rate. It varied from $0.0410^{-2}$ to $1.45 \mathrm{~g} \mathrm{~m}^{-1} \mathrm{~s}^{-1}$ at individual measurement sites. Channel-mean bedload transport rate $\left(\mathrm{q}_{\mathrm{a}}\right)$ amounted to $0.09 \mathrm{~g} \mathrm{~m}^{-1} \mathrm{~s}^{-1}$, and the mean value at individual sites varied from 0.004 to $0.16 \mathrm{~g} \mathrm{~m}^{-1} \mathrm{~s}^{-1}$ for a 24-hour interval. In the period analysed, the river discharged a total of approx. $1834 \mathrm{~kg}$ of bedload, with mean daily bedload transport rate $\left(\mathrm{Q}_{\mathrm{b}}\right)$ of approx. $63 \mathrm{~kg} \mathrm{day}^{-1}$. The volume and rate of bedload transport were dependent on hydrodynamic conditions and stream regime, directly related to weather. Also the effect of Scott Glacier retreat on discharge rate was emphasised, along with the indicative character of bedload transport rate. It responds to changes in the tempo and magnitude of processes in a glacial catchment quite rapidly, and therefore can be treated as a good indicator of transformations occurring in the arctic zone.

Keywords: arctic fluvial system, the Scott River catchment, bedload transport rate, Svalbard.
\end{abstract}

\section{Introduction}

Bedload transport rate can be an important indicator of contemporary transformations of fluvial catchments of the arctic zone, along with thoroughly researched indicators such as glacier mass balance [e.g. 1-4], water balance [5] or thickness of active permafrost layer [e.g. 6-8]. Scarcity of papers on the 
subject and problems with representativeness of measurements are the main reasons for low level of knowledge on bedload transport rate and its relation to the remaining components of fluvial transport in the zone [9-15]. Difficult terrain and climatic conditions, high variability of bedload transport, and problems with estimation of measurement efficiency make it difficult to apply modern, direct, and continuous monitoring methods such as: luminescent, magnetic, radio-emitter, radioisotope, or acoustic method [e.g. 9, 16-27]. Due to the short term and spot character of measurement, application of Helley-Smith samplers can also result in low representativeness and limited measurement efficiency, particularly in the case of medium- and coarse-grained fractions [22, $28,29]$. Direct and continuous $(24 \mathrm{~h})$ measurement in anchored RBT devices, distributed proportionally in the channel cross-section, combines facility of use of portable samplers with the efficiency of continuous measurement systems, with simultaneous lack of restrictions in terms of duration of a measurement series [30]. Data obtained in this manner permit determination of bedload transport rate as well as conditions of bedload transport and its relation to discharge and other hydrodynamic parameters.

A detailed study was carried out in the Scott River catchment, where the range of the glacier terminus and changes in its geometry, as well as proglacial discharge have been monitored since 1986 [31-33]. The existing measurement series allows for undertaking an attempt to estimate directions and rate of environmental transformations in the arctic zone with the application of bedload transport rate analysis.

\section{Study area}

The Scott River catchment with glacial alimentation regime is located in the NW part of the Wedel-Jarlsberg Land in the area of the Bellsund Fjord on Spitsbergen (fig. 1). It occupies an area of approximately $10 \mathrm{~km}^{2}$. Its mean height reaches $267 \mathrm{~m}$ a.s.1., with mean slope inclination of $12.6^{\circ}$ [33].

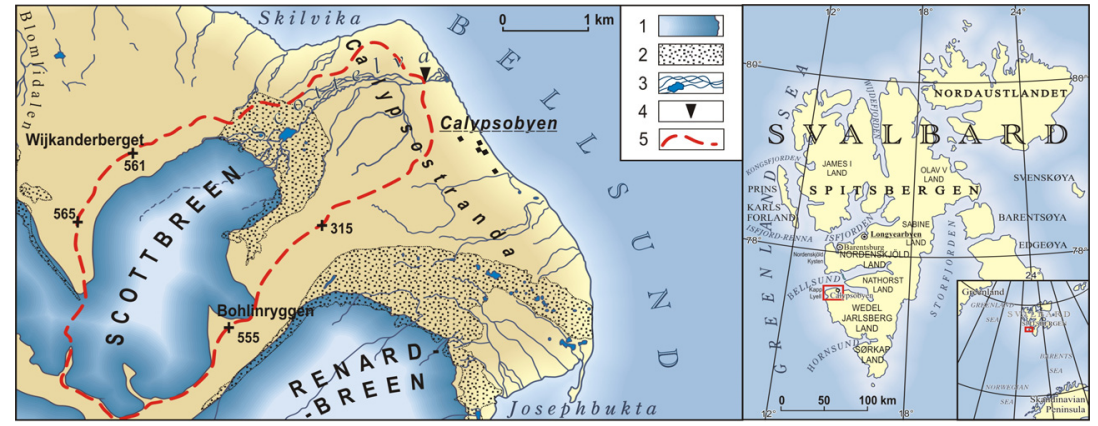

Figure 1: Location of the study area. Location of the Scott River catchment: 1. valley glaciers; 2 . glacial accumulation zones; 3 . rivers and water bodies; 4. location of river gauge and study profiles (Kociuba et al. [30]). 
Almost half of the catchment is occupied by the valley Scott Glacier in the phase of strong recession (approx. $4.7 \mathrm{~km}^{2}$ ), with a length of approx. $4 \mathrm{~km}$ and width from 1.1 to $1.8 \mathrm{~km}$ [4]. The highest parts of the glacier reach $600 \mathrm{~m}$ a.s.1., and the terminus $90 \mathrm{~m}$ a.s.l. The marginal zone of the glacier includes a typical group of glacial (moraines, kames) and glaciofluvial landforms (outwash fans), and is the effect of rapid changes in location of the glacier terminus after the end of the Little Ice Age. The currently observed recession and downwearing of the glacier terminus were interrupted in the 1960s, when rapid surge of the glacier was recorded in the form of push moraines. From this stage, retreat of the glacier terminus has been observed at a rate from 12 (the 1960s and 1970s) to max. $37 \mathrm{~m}$ $\mathrm{y}^{-1}$ (1990s). Within the last several years, the rate amounts to approx. $10 \mathrm{~m} \mathrm{y}^{-1}$ [3].

The main water alimentation source for the river is Scott Glacier ablation (90\%). Contribution of precipitation and nival waters is approx. $4 \%$ each, and permafrost waters only approx. 2\%. Annually, the Scott River discharges approx, $900 \mathrm{~mm}$ of water from its catchment on the average, with mean discharge of $<1 \mathrm{~m}^{3} \cdot \mathrm{s}^{-1}$ and unit discharge of $0.1 \mathrm{~m}^{3} \cdot \mathrm{s}^{-1} \cdot \mathrm{km}^{-2}$ [34]. The discharges are distinguished by very high variability of water stages and irregularity at the daily, seasonal, and multi-annual scales. Maximum discharges (up to $12.0 \mathrm{~m}^{3} \cdot \mathrm{s}^{-1}$ ) result from ablation-precipitation flood flows [3, 31]. Occurrence of weather extremes in a very short period can significantly modify discharge conditions. This is reflected in high variability of fluvial transport [34].

\section{Study methods}

The study in the Scott River catchment covered meteorological, hydrological, and sediment transport monitoring. Fluvial transport measurements were conducted at $2.5 \mathrm{~km}$ of the river's course, in the lower section of the Scott River gorge in the elevated marine terraces. The cross-profile was established in the narrowing of the gorge, where the waters of the Scott River concentrate the discharge within one stream. Meteorological (air temperature, precipitation, air pressure, humidity) and hydrological elements (water stages, temperature, water electrolytic conductivity) were recorded automatically (A-ster meteorological station and OTT pressure limnigraph) every 10 minutes, and water flow velocity was measured every 3 days by means of a current meter (HEGA type). Continuous measurement of bedload transport was performed with the application of 4 RBT samplers distributed proportionally every $1-2 \mathrm{~m}$ in the channel cross-profile (fig. 2), operating in a $24 \mathrm{~h}$ cycle. In the period from 13 July to 10 August 2010 (29 measurement days), a total of 116 samples were taken. The samples were weighed, and the material obtained was calculated per 1 $m$ of channel width, and averaged for the entire measurement profile. Measurements of the channel geometry in measurement cross-sections were performed by means of traditional geodetic methods (total station Nikon DT300). Measurements of morphology of the valley bed and slopes were carried out by means of satellite geodesy technology (GPS) and Terrestrial Laser Scanning (Leica Scan Station C10). 


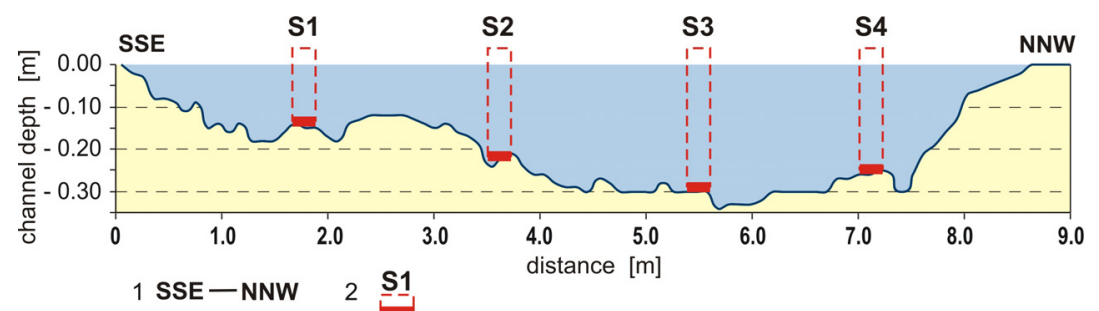

Figure 2: Diagram of bedload samplers (RBT) location in cross-section: 1. cross-section, 2. channel bed, 3. measurement site (S1-S4).

\section{Results}

In the summer season 2010, the weather and meteorological conditions were colder and dryer than in other years (2005-2009), but no significant weather anomalies occurred. Air temperature in the measurement period ranged from $+1.9^{\circ} \mathrm{C}$ to $+6.2^{\circ} \mathrm{C}$, with a mean of $+4.5^{\circ} \mathrm{C}$ (fig. 3). Precipitation total in the measurement period $(8.6 \mathrm{~mm})$ was slightly lower than the multi-annual value. During the 7 precipitation days observed, the maximum daily total did not exceed $3.0 \mathrm{~mm}$, and differed considerably from the maxima recorded previously in 1993 (36 mm) (Bartoszewski [31]).

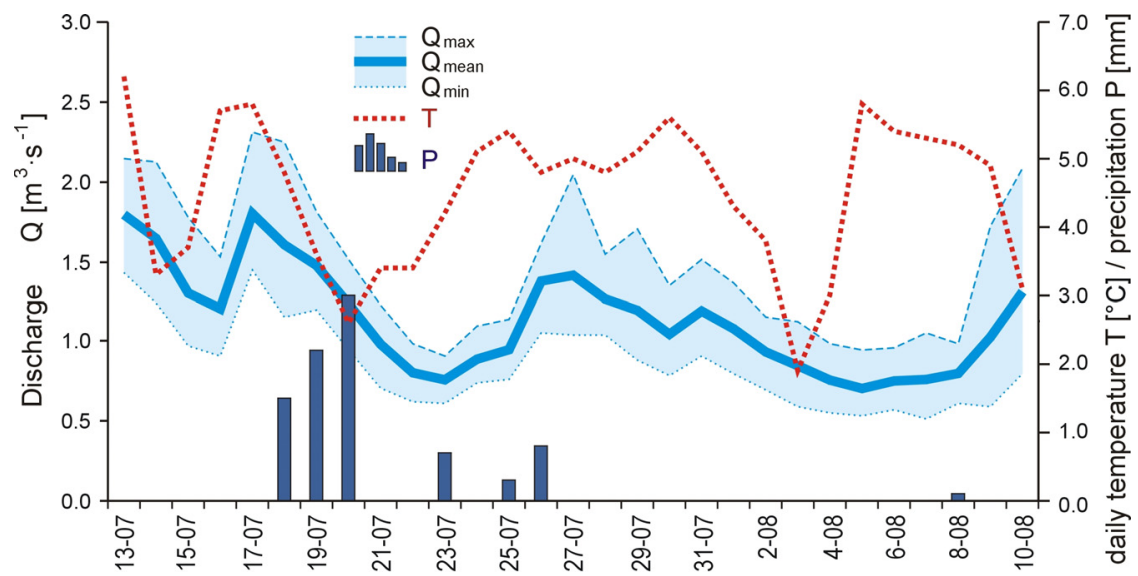

Figure 3: Comparison of the course of changes of mean daily air temperature and mean daily precipitation total in the "Calypsobyen" research station of the Maria Curie-Skłodowska University with mean daily discharge in the Scott River in the summer season 2010: P precipitation, $\mathrm{Q}$ - daily discharge, $\mathrm{T}$ - mean daily air temperature.

In the measurement period, water stage in the Scott River channel ranged from 12 to $25 \mathrm{~cm}$ (mean $13.3 \mathrm{~mm}$ ). Mean daily discharge ranged from 0.7 to $2.3 \mathrm{~m}^{3} \cdot \mathrm{s}^{-1}$, and was similar to mean values $\left(1.1 \mathrm{~m}^{3} \cdot \mathrm{s}^{-1}\right)$. Channel-mean discharge 
in the cross-profile analysed was estimated at $3.5 \mathrm{~m}^{3} \mathrm{~s}^{-1}$. Both water stages and discharges corresponded quite well with mean daily air temperatures and daily precipitation totals (fig. 3). In the period analysed, also high variability of flow rate was observed between 0.6 and $1.3 \mathrm{~m} \mathrm{~s}^{-1}$ (mean $0.8 \mathrm{~m} \mathrm{~s}^{-1}$ ).

The results obtained suggest high variability of bedload transport dynamics in the conditions of relatively low flow discharge variability (fig. 5 or 4). Daily bedload transport rate at individual measurement sites ranged from $0.0410^{-3}$ to $1.45 \mathrm{~g} \mathrm{~m}^{-1} \mathrm{~s}^{-1}$. Mean daily transport at individual measurement sites (S1-S4) was, respectively: $0.004,0.16,0.14$, and 0.05 , and the average daily value was $0.09 \mathrm{~g} \mathrm{~m}^{-1} \mathrm{~s}^{-1}$. The maximum daily transport rate, ranging from 0.05 to $1.45 \mathrm{~g} \mathrm{~m}^{-1} \mathrm{~s}^{-1}$, was recorded during the flood on 13 July 2010. These values constituted from $27 \%$ to $45 \%$ of the total mass measured at individual measurement sites. Bedload transport rate recorded during 3 days of flood on 13-15 July constituted more than half of the entire bedload mass discharged, and at individual measurement sites, the percentage was from 44 to $54 \%$. Mean cross-profile bedload discharge $\left(Q_{b}\right)$ was estimated at almost $0.73 \mathrm{~g} \mathrm{~s}^{-1}(63 \mathrm{~kg}$ day $\left.^{-1}\right)$, i.e. approx. $1.8 \mathrm{t}$ during the measurement period. The results obtained suggest high variability of bedload transport dynamics in the conditions of relatively stable discharges, both in the daily cycle, and in the entire measurement period (fig. 4).

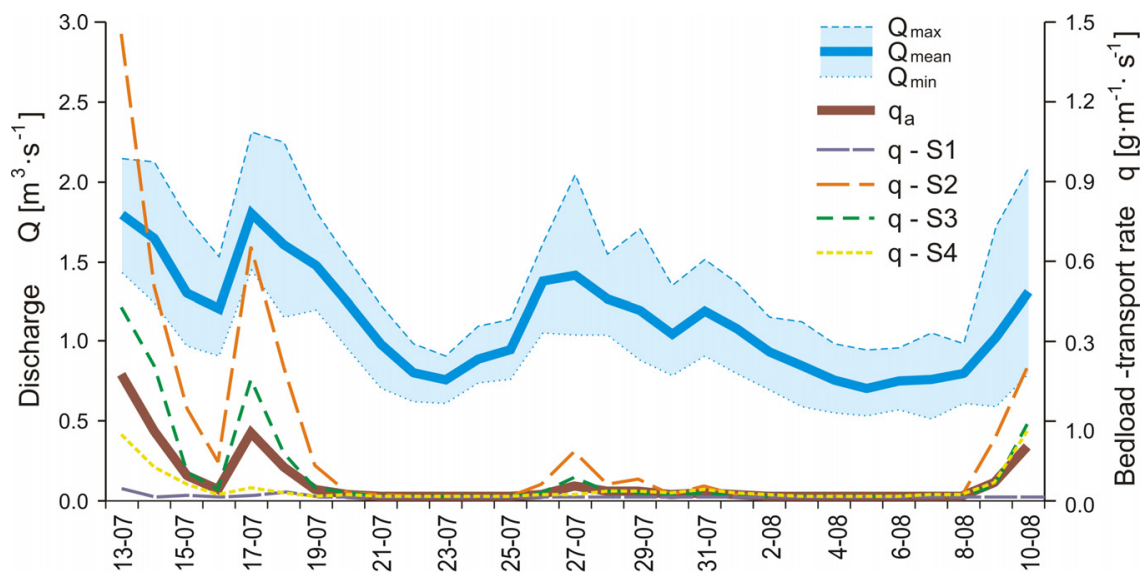

Figure 4: Hydrograph of daily discharge in the Scott River $(Q)$, and bedload transport rate $(q)$ at individual measurement sites $(q \mathrm{~S} 1-\mathrm{S} 4)$ and the channel-mean value $\left(q_{a}\right)$.

The analysis of distribution of daily bedload values confirms differentiation of bedload transport in the channel cross-section (fig. 4). Throughout the measurement period, dominance of loads in the thalweg zone was observed (S2, S3). Temporal differentiation of bedload transport was also visible. At the beginning of the measurement period, i.e. from 13.07 to 15.07 , significantly higher bedload transport rates and its high variability at individual sites were recorded as a result of high discharge dynamics in the Scott River (fig. 4). 
In the remaining period, the registered loads were usually insignificant, and distinguished by better correlation with mean daily discharge (fig. 5). The regression analysis (fig. 5B) suggests a direct relation between bedload transport rate and mean discharge $\left(R^{2}=0.63\right)$. For individual measurement sites, however, the relations are strongly varied (fig. 5A). At outer measurement sites (S1 and $\mathrm{S} 4)$, located in the pool area, the relations are weak $\left(R^{2}=0.49\right.$ and 0.36$)$. At sites (S2 and S3) in the thalweg zone, they are stronger than the average $\left(R^{2}=0.65\right.$ and 0.66$)$.

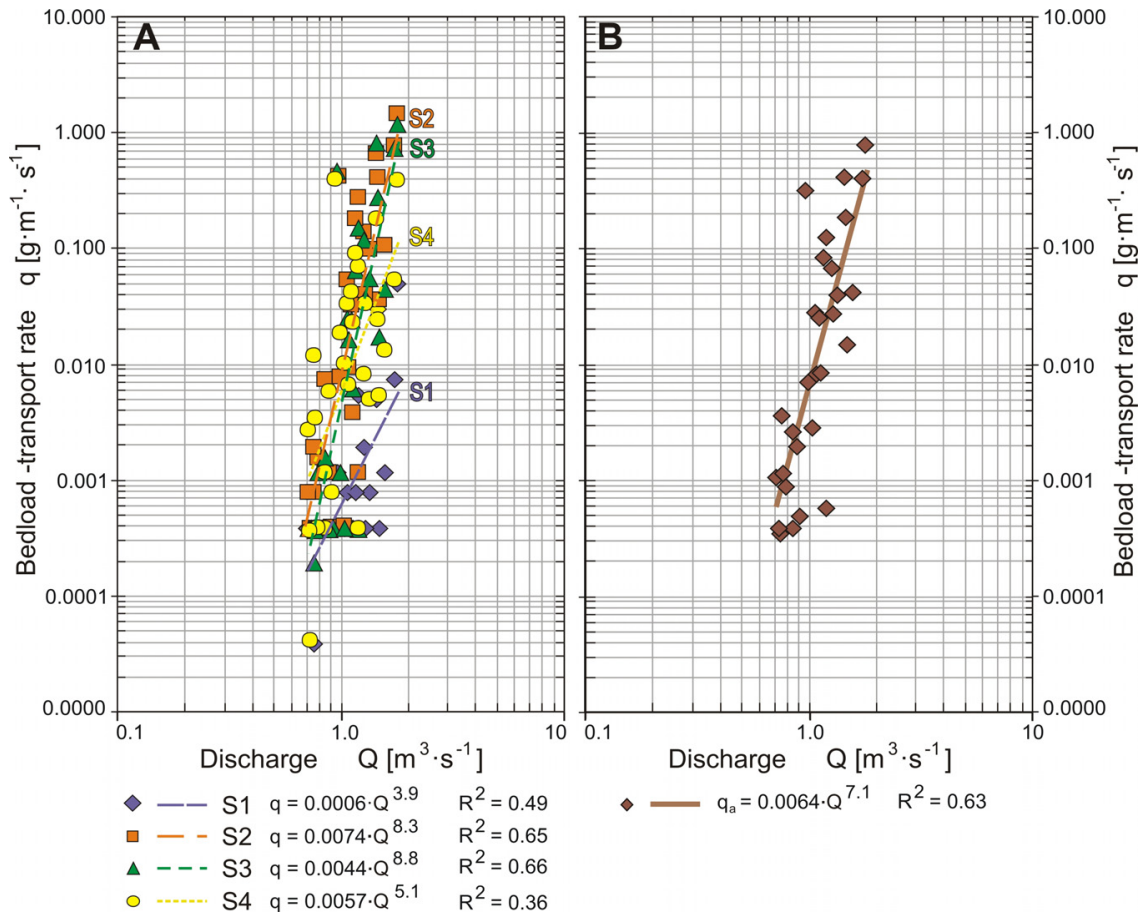

Figure 5: $\quad$ Relation between bedload transport rate $(q)$ and discharge $(Q)$ value in the measurement period at individual measurement sites (A) and the channel-mean value (B).

Efficient bedload transport suggests that the threshold value of discharge accompanying initiation of movement varies between 1.1 and $1.3 \mathrm{~m}^{3} \mathrm{~s}^{-1}$, and in the case of termination of movement, it is slightly lower, i.e. $1.0-1.1 \mathrm{~m}^{3} \mathrm{~s}^{-1}$ (fig. 4).

\section{Discussion}

The obtained low bedload transport values in comparison to rivers of other regions of the Arctic $[10,15]$ or montane areas [35] are related to quite rapid recession of Scott Glacier terminus within the last decade, lately accompanied by 
a decrease in discharges [3, 31]. It should be emphasised, however, that the ablation season 2010 was one of the coldest and driest within the last five years. This may additionally limit intensiveness of glacial ablation, the main alimentation source of the Scott River. The relation between proglacial discharge and weather conditions is confirmed by 20 years of observation conducted in the Scott River catchment [3, 31, 32], as well as in other catchments of Svalbard [5, 36-39]. Also studies conducted in other cold climate zones confirm high instability and irregularity of fluvial transport. The main factors modifying its rate include intensiveness of ablation processes, occurrence of violent ablation and precipitation flood flows, and in the case of Iceland - jökulhlaup catastrophic outburst floods [40-46].

Those phenomena seem to confirm high sensitivity of the polar environment to the observed global climate changes [1, 32, 43, 47, 48]. It seems, however, that the response of polar rivers to weather conditions is non-linear, and largely dependent on the history of the environment (e.g. Little Ice Age, glacier surges) and fluvial system evolution. Therefore, estimation of fluvial transport efficiency should consider the palaeogeographical aspect $[15,49,50]$.

\section{Conclusions}

The results obtained suggest variable bedload transport dynamics. Its rate at individual measurement sites ranged from 0.25 to $547 \mathrm{~kg}_{\text {day }}{ }^{-1}$. More than half of bedload transported was discharged during three days of flood. The maximum value recorded during one day constituted up to $45 \%$ of total bedload mass transported at a measurement site. Initiation and termination of bedload movement occurs within the range of medium discharges from 1.0 to $1.3 \mathrm{~m}^{3} \mathrm{~s}^{-1}$, whereas he value necessary for movement initiation is slightly higher, and corresponds with mean discharge rate from the measurement period, which constitutes approximately one third of channel-mean discharges.

Results of the one-month study in the culmination of the melt season 2010 confirm high temporal and spatial variability of bedload transport in the Scott River measurement cross-section. Bedload discharge was mainly dependent on meteorological factors (air temperatures), affecting the glacier ablation rate. Also the advanced stadium of Scott Glacier recession contributed to a decrease in provision of ablation waters. This results in low discharges in the proglacial river. In the period analysed, provision of bedload directly from the channel slopes as a result of mass processes was insignificant. They occurred in the first part of the ablation season.

Bedload transport rate can be a good and measurable indicator of changes in the regime of arctic catchments or transformations of environmental processes. Such a conclusion, however, requires longer measurement series and detailed knowledge on the mechanism of bedload provision and transport in this zone very sensitive to global changes. 


\section{Acknowledgements}

The study was conducted in the scope of the $22^{\text {nd }}$ Polar Expedition of the Marie Curie-Skłodowska University in Lublin to Spitsbergen, implementing grant of the Polish Ministry of Science and Higher Education (N N306 525738): Dynamics of matter circulation in a polar catchment subject to deglaciation processes (Scottelva, Spitsbergen). The paper was prepared in the scope of promotion of the project POIG.01.03.02-00-082/10 "Providing European patent protection for the device for measuring bedload transport in river beds" implemented by MCSU in Lublin, co-financed from the resources of the European Union in the scope of the Operational Programme Innovative Economy, years 2007-2013, Priority 1. 'Research and development of modern technologies'.

\section{References}

[1] Hagen, J.O. and Lefauconnier B., Reconstructed runoff from the High Arctic basin Bayelva based on mass balance measurements. Nordic Hydrology 26, pp.285-296, 1995.

[2] Jania, J. and Hagen, J.O. (eds). Mass balance of Arctic Glaciers. IASC Raport 5, 1996.

[3] Bartoszewski, S., Gluza, A., Siwek, K. and Zagórski, P., The functioning of Scott Glacier in conditions of climate global changes. Landform Analysis $\mathbf{5}$, pp.5-8, 2007.

[4] Zagórski, P., Siwek, K., Gluza, A. \& Bartoszewski, S., Changes in the extent and geometry of the Scott Glacier, Spitsbergen. Polish Polar Research 29, 2, pp.163-185, 2008.

[5] Killingtveit, A., Pettersson, L.E. \& Sand, K., Water balance investigations in Svalbard. Polar Research 22, pp.161-174, 2003.

[6] Marsz, A.A., Pękala, K., Repelewska-Pękalowa, J. \& Styczyńska, A., Changeability of maximal thickness of active permafrost layer in the Bellsund Region (W Spitsbergen) in the period 1986-2009. Problemy Klimatologii Polarnej 21, pp.133-154, 2001.

[7] Pękala, K. \& Repelewska-Pękalowa, J., Dynamics of active layer of permafrost. Landform Analysis 5, pp.168-169, 2007.

[8] Etzelmüller, B., Schuler, T.V., Isaksen, K., Christiansen, H.H., Farbrot, H. \& Benestad, R., Modeling the temperature evolution of Svalbard permafrost during the 20th and 21st century. Cryosphere 5, pp.67-79, 2011.

[9] Bogen, J. \& Møen, K., Bedload measurements with a new passive acoustic sensor. Erosion and Sediment Transport Measurement in Rivers. Technological and Methodological Advances, eds. J. Bogen, T. Fergus \& D. Walling, IAHS Publ. 283, pp.201-210, 2003.

[10] Ashworth, P.J. \& Ferguson, R.I., Interrelationships of channel processes, changes and sediments in a proglacial braided river. Geografiska Annaler 68A (4), pp.361-371, 1986. 
[11] Carson, M.A. \& Griffiths, G.A., Bedload transport in gravel channels. Journal of Hydrology (NZ) 26, pp.1-151, 1987.

[12] Beylich, A.A., Quantitative studies on sediment fluxes and sediment budgets in changing cold environments - potential and expected benefit of coordinated data exchange and the unification of methods. Landform Analysis 5, pp.9-10, 2007.

[13] Zwoliński, Z., Hydrological polar monitoring - methodical proposition. Monitoring Środowiska Przyrodniczego 8, pp.29-39, 2007 (in Polish).

[14] Beylich, A.A. \& Kneisel, C., Sediment budget and relief development in Hrafndalur, subarctic oceanic Eastern Iceland. Arctic, Antarctic, and Alpine Research 41, pp.3-17, 2009.

[15] Orwin, J.F., Lamoureux, S.F., Warburton, J. \& Beylich, A.A., A framework for characterizing fluvial sediment fluxes from source to sink in cold environments. Geografiska Annaler 92A, 2, pp.155-176, 2010.

[16] Milhous, R., Sediment transport in a gravel-bottomed stream. Ph.D. thesis, Oregon State University: Corvallis, USA, 1973.

[17] Hayward, J.A. \& Sutherland, A.J., The Torlesse stream vortex-tube sediment trap. Journal of Hydrology (N.Z.) 13(1), pp.41-53, 1974.

[18] Reid, I., Layman, J.T. \& Frostick, L.E., The continuous measurement of bedload discharge. Journal of Hydraulic Research 18, pp.243-249, 1980.

[19] Ergenzinger, P. \& Conrady, J., A new tracer technique for measuring bedload in natural channels. Catena 9, pp.77-80, 1982.

[20] Tacconi, P., Billi, P., Bedload transport measurement by a vortex-tube trap on Virginio Creek, Italy. Sediment Transport in Gravel-Bed Rivers, eds. C.R. Thorne, J.C. Bathurst \& R.D. Hey, John Wiley: Chichester, pp.583$615,1987$.

[21] Lewis, J., An improved bedload sampler. Proceedings of the Fifth Federal Interagency Sedimentation Conference, Las Vegas, Nev., Subcommittee of the Interagency Advisory Committee on Water Data, pp.61-68, 1991.

[22] Hey, R.D. \& Meigh, J.R., Distribution and sedimentary characteristics of bedload transport in gravel-bed rivers. VAW 117, Grain Sorting Seminar, pp.371-398, 1992.

[23] Powell, D.M., Reid, I., Laronne, J.B. \& Frostick, L.E., Cross stream variability of bed-load flux in narrow and wide ephemeral channels during desert flash floods. Gravel-Bed Rivers in the Environment, eds. P.C. Klingeman, R.L. Beschta, P.D. Komar \& J.B. Bradley, Water Resources Publications LLC, Highlands Ranch, Colorado, pp.177-196, 1998.

[24] Garcia, C., Laronne, J. B. \& Sala, M., Continuous monitoring of bedload flux in a mountain gravel-bed river, Geomorphology 34, 1-2, pp.23-31, 2000.

[25] Sear, D.A., Damon, W., Booker, D.J \& Anderson, D.G., A load cell based continuous recording bedload trap. Earth Surface Processes and Landforms 25, pp.689-672, 2000.

[26] Reid, I., Laronne, J.B \& Powell, M., The Nahal Yatir bedload database: sediment dynamics in a gravel-bed ephemeral stream. Earth Surface Processes and Landforms 20, pp.845-857, 2002. 
[27] Downing, J.P., Farley, P.J., Bunte, K., Swingle, K., Ryan, S.E. \& Dixon, M., Acoustic gravel-transport sensor: description and field tests in Little Granite Creek, Wyoming, USA. Erosion and Sediment Transport Measurement in Rivers: Technological and Methodological Advances, eds. J. Bogen, T. Fergus \& D.E. Walling, IAHS Publication 283, pp.193-200, 2003.

[28] Helley, E.J. \& Smith, W., Development and calibration of a pressuredifference bedload sampler. US Geological Survey Open-File Report, 1971.

[29] Emmett, W.W., A field calibration of the sediment-trapping characteristics of the Helley-Smith bedload sampler, US Geological Survey Professional Paper, 1139, 1980.

[30] Kociuba, W., Janicki, G. \& Siwek, K., Dynamics of changes the bedload outflow from a small glacial catchment (West Spitsbergen). Monitoring, Simulation, Prevention and Remediation of Dense Debris Flow III, eds. D. de Wrachien \& C.A. Brebbia, WIT Press: Southampton and Boston, pp.261-270, 2010.

[31] Bartoszewski, S., Regime of outflow of the Wedel Jarlsberg's Land rivers (Spitsbergen). Faculty of Biology and Earth Sciences MCSU in Lublin: Habilitation dissertations 40, Lublin, 1998 (in Polish).

[32] Bartoszewski, S., Gluza, A., Siwek, K. \& Zagórski, P., Temperature and rainfall control of outflow from the Scott Glacier catchment (Svalbard) in the summers of 2005 and 2006. Norsk Geografisk Tidsskrift - Norwegian Journal of Geography 1502-5292, 63, 2, pp.107-114, 2009.

[33] Zagórski P., Bartoszewski S., Chmiel S., Gluza A., Siwek K., Superson J., Monitoring of the Scottelva Catchment (The NW part of Wedel Jarlsberg Land, Spitsbergen). Quaestiones Geographicae 27A, 2, pp.115-129, 2008 (2010).

[34] Kociuba, W., Janicki, G. \& Siwek, K., Variability of sediment transport in the Scottelva catchment in the hydrologically active season of 2009. Quaestiones Geographicae, 2012 [in print].

[35] Warburton J., An alpine proglacial fluvial sediment budget. Geografiska Annaler 72A, 261-272, 1990.

[36] Repp, K., The hydrology of Bayelva, Spitsbergen. Nordic Hydrology 4, 259-268, 1988.

[37] Sollid, J.L., Etzemüller, B, Vatne, G. \& Ødegard, R., Glacial dynamics, material transfer and sedimentation of Erikbreen and Hannabreen, Liefdefjorden, northern Spitsbergen. Zeitschrift für Geomorphologie. Supp. B. 97, pp.123-144, 1994.

[38] Sobota, I., Ablation and discharge of the Waldemar Glacier, north-western Spitsbergen, in summer 1998. Polish Polar Research 21(1), pp. 3-18, 2000.

[39] Wulfe, M. \& English, M.C., Hydro meteorological relationships in a glaciarized catchment in the Canadian high Arctic. Hydrological Processes 9, 8,911-921, 1995.

[40] Church, M. \& Gilbert, R., Proglacial fluvial and lacustrine environments. Glaciofluvial and glaciolacustrine sedimentation, eds. A.V. Jopling \& B.C. 
McDonald, Society of Economic Palaeontologists and Mineralogists Special Publication No. 23, pp.22-100, 1975.

[41] Gilbert, R. \& Church, M., Contemporary sedimentary environments on Baffin Island, N.W.T., Canada: reconnaissance of lakes on Cumberland Peninsula. Arctic and Alpine Res. 15(3), pp. 321-332, 1983.

[42] Hasholt, B., Hydrology and Transport of Material in the Sermilik Area 1972. Geografisk Tidsskrift 75, pp.30-39, 1976.

[43] Kjeldsen, O. \& Østrem, G., Materialtrans-portundersokelser and Norske Breelver 1979. NorgesVassdragsogElektrisitetsvesen. Vassdragsdirektoratet Hydrologisk Avdeling Rapport, 1980.

[44] Østrem, G., Bridg, C.W. \& Rannie, W.F., Glacio-hydrology, discharge and sediment transport in the Decade Glacier area, Baffin Island, N.W.T. Geografiska Annaler 49A, pp.268-282, 1967.

[45] Pearce, J.T., Pazzaglia, F.J., Evenson, E.B., Lawson, D.E., Alley, R.B., Germanoski, D. \& Denner, J.D., Bedload component of glacially discharged sediment: Insights from the Matanuska Glacier, Alaska. Geology 31, pp.7-10, 2003.

[46] Rachlewicz, G., Floods in high Arctic Valley systems and their geomorphologic effects (examples from Billefjorden, Central Spitsbergen). Landform Analysis 5, pp.66-70, 2007.

[47] Hodson, A., Tranter, M., Gurnell, A., Clark, M. \& Hagen, J.O., The hydrochemistry of Bayelva, a high Arctic proglacial stream in Svalbard. Journal of Hydrology 257, pp.91-114, 2002.

[48] Kostrzewski, A., Kaniecki, A., Kapuściński, J., Klimczak, R., Stach, A. \& Zwoliński, Z., Dynamics and rate of denudation of a glaciated and an unglaciated catchments, Central Spitsbergen. Polish Polar Research 10, 3, pp.317-367, 1989.

[49] Harasimiuk, M. \& Król, T., The dynamics of morphogenetic and sedimentary processes in the estuary segments of river valleys of the Recherche Fjord (Western Spitsbergen). Spitsbergen Geographical Expeditions of Marie Curie-Skłodowska University, MCSU Press: Lublin, pp. 59-66, 1992.

[50] Marren, P.M., Magnitude and frequency in proglacial rivers: a geomorphological and sedimentological perspective. Earth-Science Reviews 70, pp. 203-251, 2005. 